\title{
ПРОБЛЕМА МНОЖЕСТВЕННОСТИ ПОДХОДОВ К ВОПРОСУ СООТНОШЕНИЯ ГОСУДАРСТВА И ПРАВА
}

\author{
(c) 2019 Ибрагимов Юсуп Муслимович \\ ассистент кафедры теории и технологии социальной работы \\ Чеченский государственный университет, Чеченская Республика, Грозный \\ E-mail: yusuf_ibr@mail.ru \\ (c) 2019 Ибрагимов Юнус Муслимович \\ студент-магистрант юридического факультета \\ Чеченский государственный университет, Чеченская Республика, Грозный \\ E-mail: yunus080496@gmail.com
}

Статья посвящена анализу различных подходов к вопросу соотношения государства и права. Автор характеризует каждый подход в отдельности и на основе проведенного анализа приходит к выводу о невозможности существования исследуемых категорий в отдельности друг от друга.

Ключевые слова: государство, право, соотношение, подходы.

Государство и право - неотделимые друг от друга понятия. Поэтому возникают проблемы с соотношением этих терминов и понятий. Соотношение государства и права излагается как отношение взаимной зависимости и приводится к тому: зависит ли государство от права, или право от государства. Эта проблема является одной из значимых проблем современной юридической науки и правовой политики. В данной работе мы выскажем свое мнение по данной теме. Однако для начала, нужно разобраться с терминологией этих понятий.

Государство - это властно-политическая организация общества, обладающая государственным суверенитетом, специальным аппаратом управления и принуждения, государственной казной и устанавливающая правовой порядок на определенной территории [1, С.4]. Смысл юридического понимания права выражен так: право - социальный институт, имеющий свою собственную природу [4, С. 223]. В отличие от государства, право обладает совокупностью общеобязательных норм, установленных или санкционированных государством и обеспечиваемых его принудительной силой. Из этого следует, что право не может существовать без государства, а государство без права, и в этом же заключается их связь между собой.

При изучении данной проблемы в юридической литературе принято выделять пять подходов, которые обычно упоминаются в качестве значимых для систематизации и описания исследуемых юридических категорий.
Первый подход этатистский. В основе данного подхода государство является главным институтом общества. Право же находится в подчиненном государству отношении, приводится в виде атрибута государства, обязательного приложения к государственной власти. Исходя из этого подхода, государство не взаимодействует с правом, а устанавливает между ними право, которое считается необходимым и нужным для государства [3, С. 148].

Второй подход выработался на основе естественно-правовых воззрений. В нем государство зависит от права, так как государство возникает в целях обеспечения действия права как системы нормативного регулирования [2, С. 88]. Такая интерпретация проблем соотношения государства и права является центром для утверждения верховенства права.

Третий подход - дуалистический. Государство и право, взаимно дополняют друг друга [3, С. 149]. Государство не может существовать без права, право без государства. Они вместе достигают совместного результата, в котором заинтересовано общество.

Четвертый подход именуется как позитивистский. В данном подходе государство выделяет самоограничения, издает законы, и, следовательно, само же обязано подчиняться этим законам [2, С. 89].

Пятый подход - либерально-демократический. Этот подход исходит из связанности государства с правом [3, С. 150].

Из вышесказанного следует, что, говоря о ка- 
тегории взаимосвязи государства от права, нужно раскрывать следующие аспекты:

Во-первых, она зависит от внутренней организации государства, в которой осуществляется связь между его отдельными частями. Право, в свою очередь, оформляет структуру и взаимодействие между элементами механизма государства, также оно способно регулировать отношения между отдельными государственными органами, создавая гарантии против скопления государственной власти в одной из ее ветвей власти, а в федерации - разграничивает предметы ведения между центром и субъектами федерации.

Во-вторых, взаимосвязь государства от права осуществляется через взаимодополнение, которое хорошо раскрывается во внешних проявлениях государства, в той роли, которую оно играет в общественных отношениях.

Давление права на государство является необходимостью. Оно четко проявляется в отношении к населению, распределении пределов воздействия государства на личность, ее права и обязанности, правовые гарантии со стороны государства. Равным образом, право придает деятельности государства легальный характер, вводя его деятельность в юридические рамки, определяя пределы государственного вмешательства в частную жизнь, пределы, формы и основания для применения государственного принуждения. Но нужно обратить внимание на то, что право в силе ограничить государство от себя, и не допустить его произвола, только в том случае если сама власть будет ограничиваться.

На основании всего вышеизложенного, учитывая связь между государством и правом, следует отметить, что право относительно самостоятельно по отношению к государству, так и наоборот. Нужно иметь в виду ту мысль, что законодательство государства не всегда может соответствовать праву. Но государственная власть, в отличие от права, может приводиться в виде непосредственной правообразующей и обеспечивающей силы, а право в свою очередь, несет по отношению к государству роль организатора.

Взаимная связь понятий государства и права проявляется в разных взаимных влияниях. Изучая влияние государства на право, можно выявить следующее: государство снабжает действия права с помощью организации судебной и исполнительной власти, надзорной и контрольной деятельности возникновение правовой нор- мы, приводя свои властные особенности в общеобязательный характер. Государство, влияя на право, создает, изменяет, реализует, охраняет от ошибочных действий.

По мнению Н. Неновского «Право формируется при непременном участии государства, оно есть непосредственный продукт, результат государственной деятельности» [3, с. 36].

Отходя от позитивистской концепции понимания проблемы, О.В.Макаров связывает воздействие государства на право с оказанием субъектам права со стороны государства содействия в реализации прав, свобод и обязанностей, а также с достижением максимального сочетания правовой нормы, устанавливаемой законодательным путем, и права как продукта потребностей и интересов нормальной человеческой деятельности [4].

В современной литературе приводятся три примерные модели о взаимоотношениях государства и права: первая - тоталитарная. Право находится в зависимости от государства; вторая модель - либеральная, тут право господствует над государством.

По нашему мнению, именно третья модель реализуема и более подходит сегодняшним условиям; третья модель - прагматическая, данный подход позволяет выявить роль государства в обеспечении права. Государство здесь связано с правом и создает его.

Исходя из этого подхода, можно охарактеризовать его главные черты: различие; взаимодействие; единство.

Основным признаком различия, является несоответствие государства и права, поэтому государство определяется как особая форма существования общества, а право - это совокупность правил поведения.

Взаимодействие государства и права состоит в том, что государство создает право. Следовательно, можно сказать, что влияние государства на право происходит неразрывно.

Единство государства и права заключается в сходности их признаков, типов. Они служат регулятором общественных отношений. В то же время эти понятия остаются самостоятельными и уникальными.

Таким образом, между государством и правом существует взаимосвязь, которая рассматривается как при теоретическом понимании этих институтов, так и в процессе демократических изменений, которые проводятся в стране, 
так же в государственно-правовой области. Пра- России настоящее гражданское общество невозво обособляет государство в законные юриди- можно, а также обеспечить в нем стабильность, ческие рамки. Без этого понимания построить в порядок и законность.

\section{Библиографический список}

1. Бредихин А.Л. К вопросу о понятии и элементах формы государства // Государственная власть и местное самоуправление. 2013. № 5. С. 3-6.

2. Мусалов М.А. Актуальные вопросы соотношения государства и права // В сборнике: НОРМА. ЗАКОН. ЗАКОНОДАТЕЛЬСТВО. ПРАВО сборник статей Международной научно-практической конференции. 2017. С. 87-89.

3. Никитас Ю.С., Мануковская А.Н. Соотношение государства и права // В сборнике: Защита прав человека в современных условиях: теория и практика Материалы VII Международной научно-практической конференции. 2017. С. 147-151.

4. Трубин Р.О. К вопросу о понятии право в новое время // Вестник КрасГАУ. 2014. № 7 (94). С. 222-226. 